\title{
(4)
}

\section{Real Exchange Rate Volatility and Financial Integration: Evidence from Latin American Countries}

\author{
${ }^{a}$ Asma Awan, ${ }^{b}$ Imran Sharif Chaudhry, ${ }^{c}$ Furrukh Bashir, ${ }^{\mathrm{d}}$ Rashid Ahmad \\ ${ }^{a}$ Assistant Professor, Department of Economics, University of the Punjab, Lahore, Pakistan \\ Email: asma.eco@pu.edu.pk \\ ${ }^{\mathrm{b}}$ Dean, Faculty of Social Sciences, Director, School of Economics, Bahauddin Zakariya University, Multan \\ Email: imran@bzu.edu.pk \\ ${ }^{\mathrm{c}}$ Assistant Professor, School of Economics, Bahauddin Zakariya University, Multan \\ Email: furrukh@bzu.edu.pk \\ ${ }^{\mathrm{d}}$ Assistant Professor, School of Economics, Bahauddin Zakariya University, Multan \\ Email: rashid.ahmad@bzu.edu.pk
}

\begin{tabular}{ll}
\hline ARTICLE DETAILS & ABSTRACT \\
\hline History: & $\begin{array}{l}\text { This research is an endeavor to reveal the dynamic association of real } \\
\text { Accepted } 29 \text { Nov } 2020\end{array}$ \\
Available Online 31 Dec 2020 & $\begin{array}{l}\text { with international financial integration in selected eight Latin American } \\
\text { countries during 1992-2018. The estimation strategy employed in this }\end{array}$ \\
\hline Keywords: & $\begin{array}{l}\text { research is the Generalized Method of Moments (GMM) to empirically } \\
\text { Financial Integration, Real }\end{array}$ \\
Exchange Rate Volatility, Latin & significant negative impact of financial integration on real exchange rate \\
American Countries & volatility when financial integration is approximated by the Chinn-Ito \\
& index. Furthermore, output volatility and money supply volatility both \\
JEL Classification: & $\begin{array}{l}\text { significantly contributed to increasing real exchange rate instability. An } \\
\text { important policy implication is that process of financial integration }\end{array}$ \\
F20, O54 & needs to be more strengthened and shocks to output and money supply \\
& needs to be reduced to achieve lesser fluctuations of the real exchange \\
rate in Latin American countries.
\end{tabular}

(C) 2020 The authors. Published by SPCRD Global Publishing. This is an open-access article under the Creative Commons Attribution-

NonCommercial 4.0

Corresponding author's email address: imran@bzu.edu.pk

\section{Introduction}

The switching from fixed to intermediate and flexible exchange rate regimes, on average, across the globe after the collapse of Bretton Woods in 1973 and the increasing pace of international financial integration during the last four decades has heated the debate and concern of social scientists in the documentation of the impact of financial integration on exchange rate fluctuations in particular and on output fluctuations in general (for details see, Agenor (2003), Morrison and White, (2004)). In the finance literature, two divergent views related to the impact of financial integration on real exchange rate volatility are reported. According to the first view, financial liberalization has 
increased real exchange rate volatility and have destabilizing effects on the economy, particularly when attempted prematurely (for details see, Blecker (2005), Frankel and Rose, (1996), Reinhart and Smith, (2001), Stiglitz (2002)). Developing countries, on average, are prone to this effect as their financial infrastructure is weak and unable to withstand the economic shock of shifting to an open economy from an inward-looking economy especially when compared with mature economies. According to the second view, increased cross border financial liberalization has minimized real exchange rate fluctuations through increased liquidity, enhancing development, fiscal discipline, consumption smoothing, risk-sharing, and efficiency of domestic financial markets (for details see, Fischer (1998), Le Fort (2000), Goldstein and Turner, (2004), Chinn and Ito (2005), Kose et al. (2007)).

Most research done on the subject matter includes a panel of South and Southeast Asian countries, MENA countries, and developed countries whereas limited research is done in the context of Latin American countries. Therefore owing to the vacuum in literature this study is an effort to explore the impact of financial integration on exchange rate volatility in the context of selected eight Latin American countries namely Argentina, Bolivia, Colombia, Costa Rica, Haiti, Mexico, Peru, and Uruguay1 during 1992-2018.

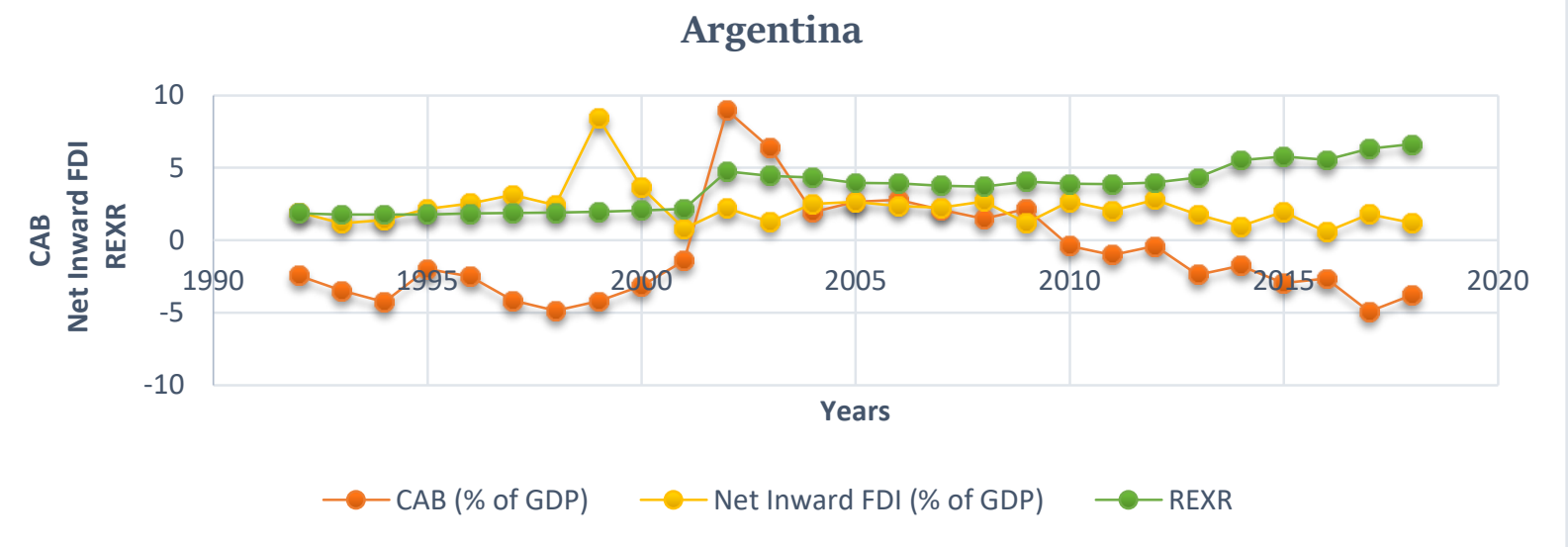

Figure 1: Current Account Balance of Argentina

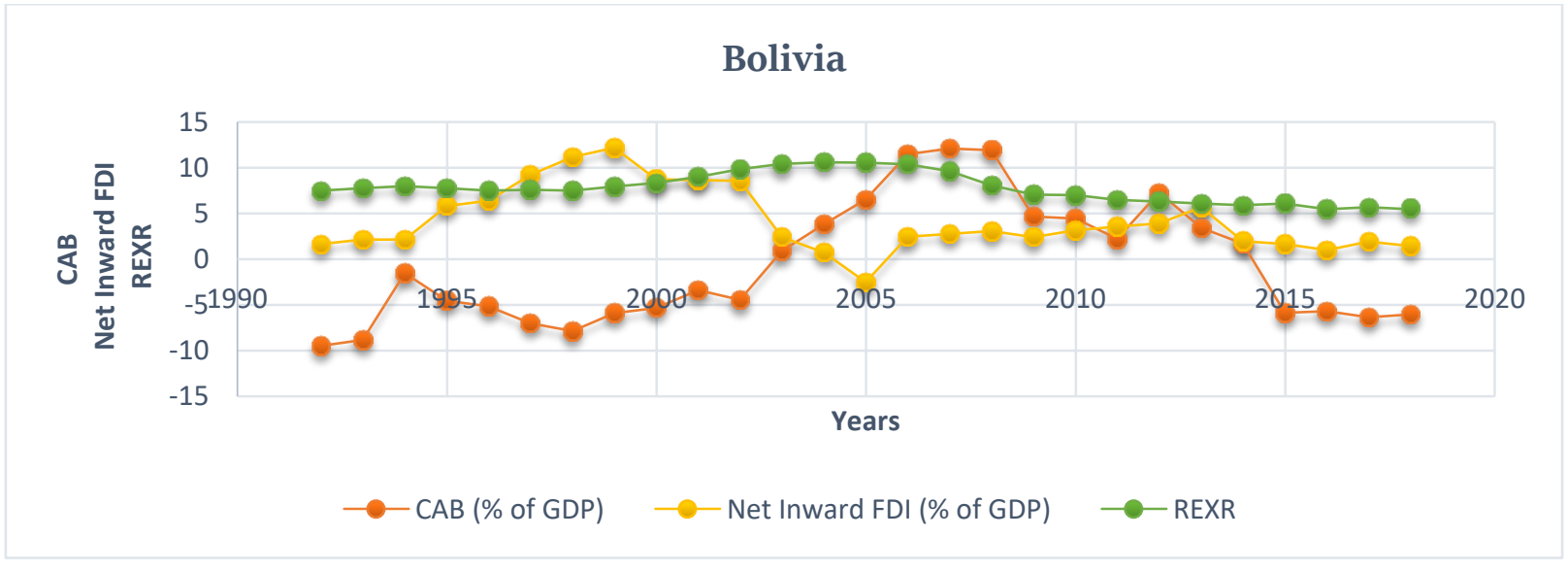

Figure 2: Current Account Balance of Bolivia

1 The length and coverage of the sample is mainly dependent on availability of data. Moreover, in sample we excluded countries that adopted fixed exchange rate regime during the whole period whereas countries are included if they adopted or moving towards free exchange rate at least half of reference period. 
In Latin American countries, the extensive borrowing is most notably done by Argentina, Brazil, and Mexico during the 1960s and 1970s became the cause of region 1982-85 severe debt and banking crises and resultant stagnant economic growth, economic depression and hyperinflation. Therefore to overcome the pitfalls of debt crises, the region implemented various structural, trade, financial, and stabilization reforms during the 1990s and this decade called a period of fundamental reforms including trade liberalization, the opening of markets, strong banking laws, abolition of capital controls, privatization and reductions of restrictions on bank loans. These reforms proved to be fruitful and promoted economic growth. Although the Mexican crises (1995) and Brazilian crises (1999) negatively affected the inflow of foreign capital but recovery was observed in following years on the backdrop of continued more sophisticated financial reforms and strong domestic demand.

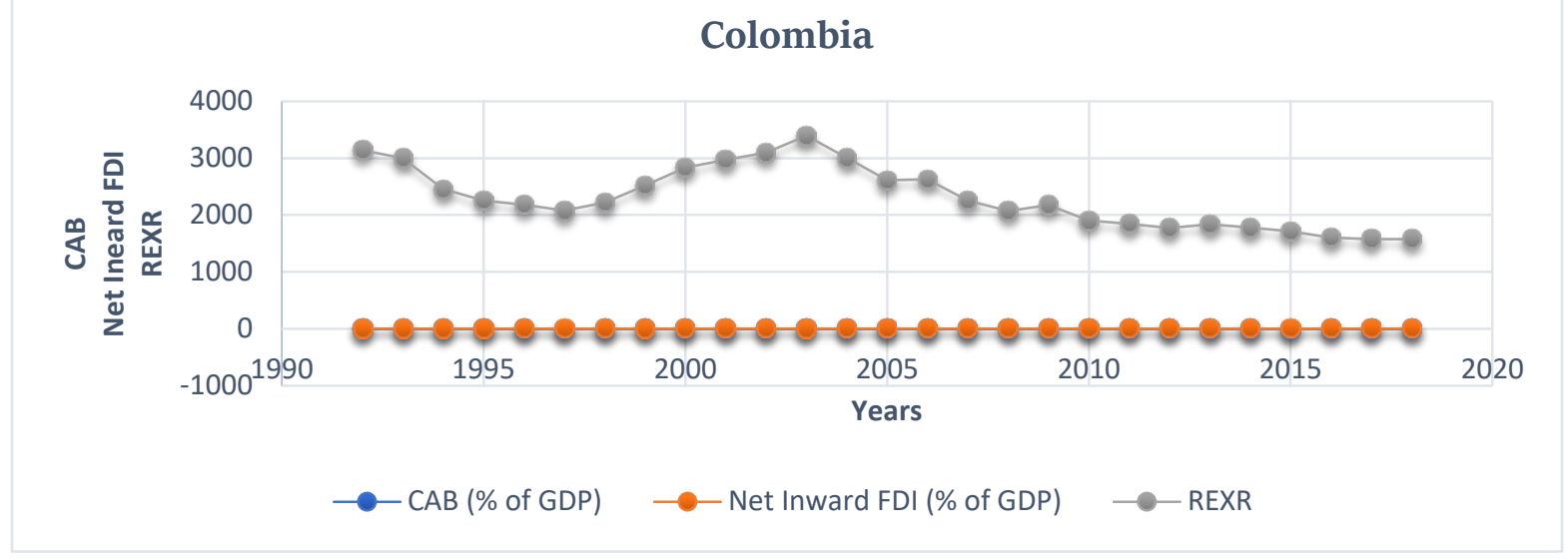

Figure 3: Current Account Balance of Colombia

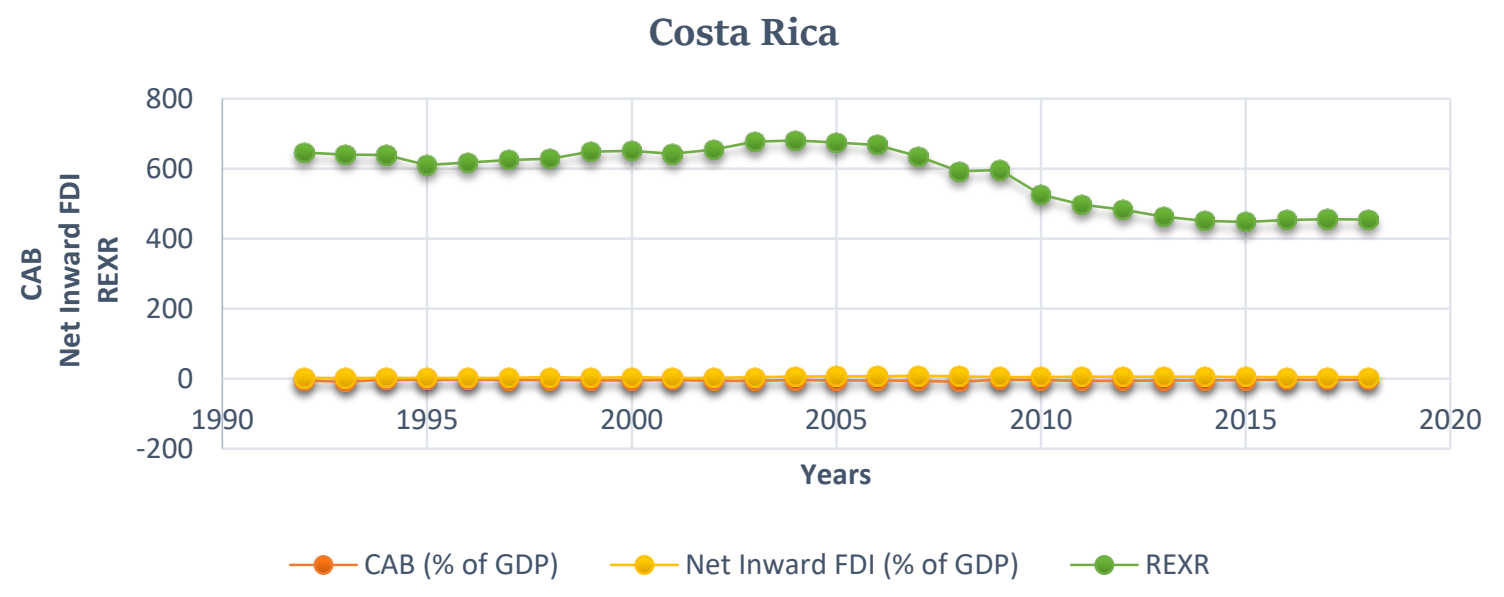

Figure 4: Current Account Balance of Costa Rica

In Latin American countries, the extensive borrowing is most notably done by Argentina, Brazil, and Mexico during the 1960s and 1970s became the cause of region 1982-85 severe debt and banking crises and resultant stagnant economic growth, economic depression and hyperinflation. Therefore to overcome the pitfalls of debt crises, the region implemented various structural, trade, financial, and stabilization reforms during the 1990s and this decade called a period of fundamental reforms including trade liberalization, the opening of markets, strong banking laws, abolition of capital controls, privatization and reductions of restrictions on bank loans. These reforms proved to be fruitful and promoted economic growth. Although the Mexican crises (1995) and Brazilian crises (1999) negatively affected the inflow of foreign capital but recovery was observed in following years 
on the backdrop of continued more sophisticated financial reforms and strong domestic demand.

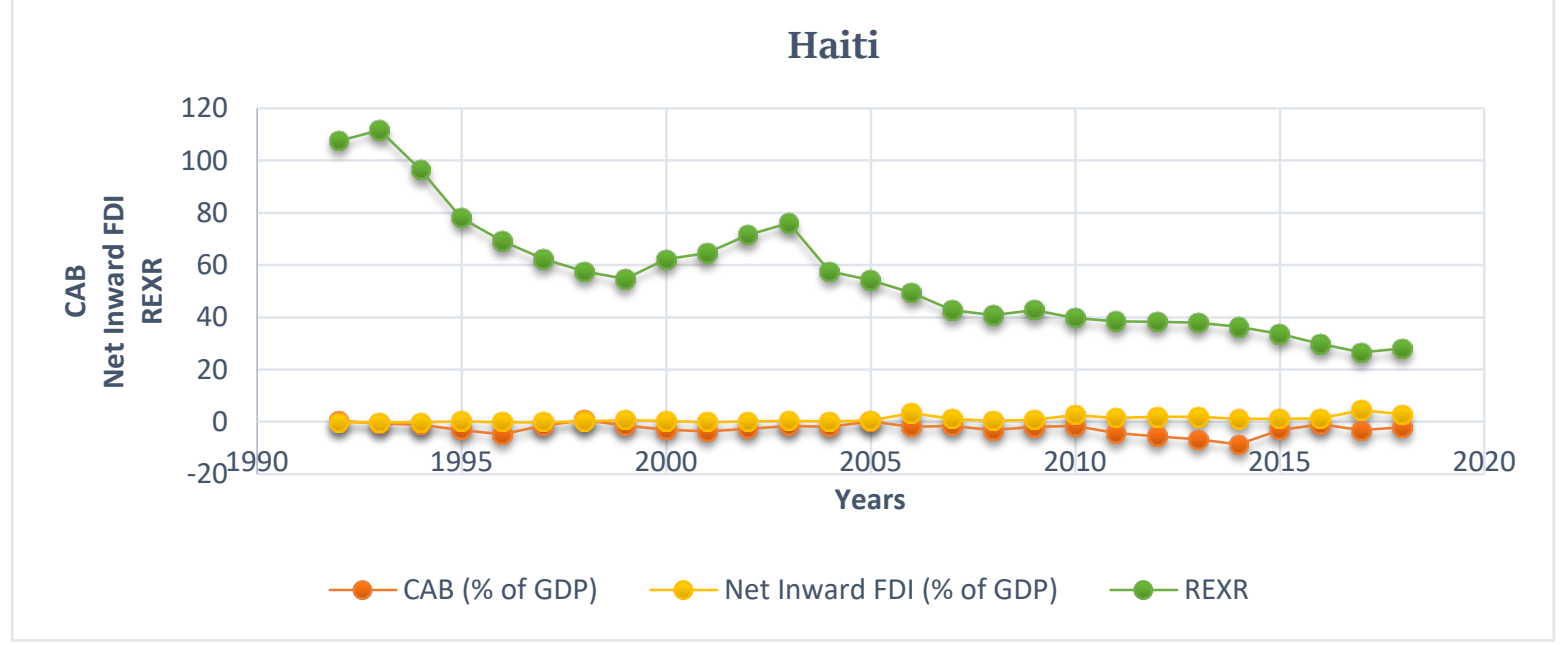

Figure 5: Current Account Balance of Haiti

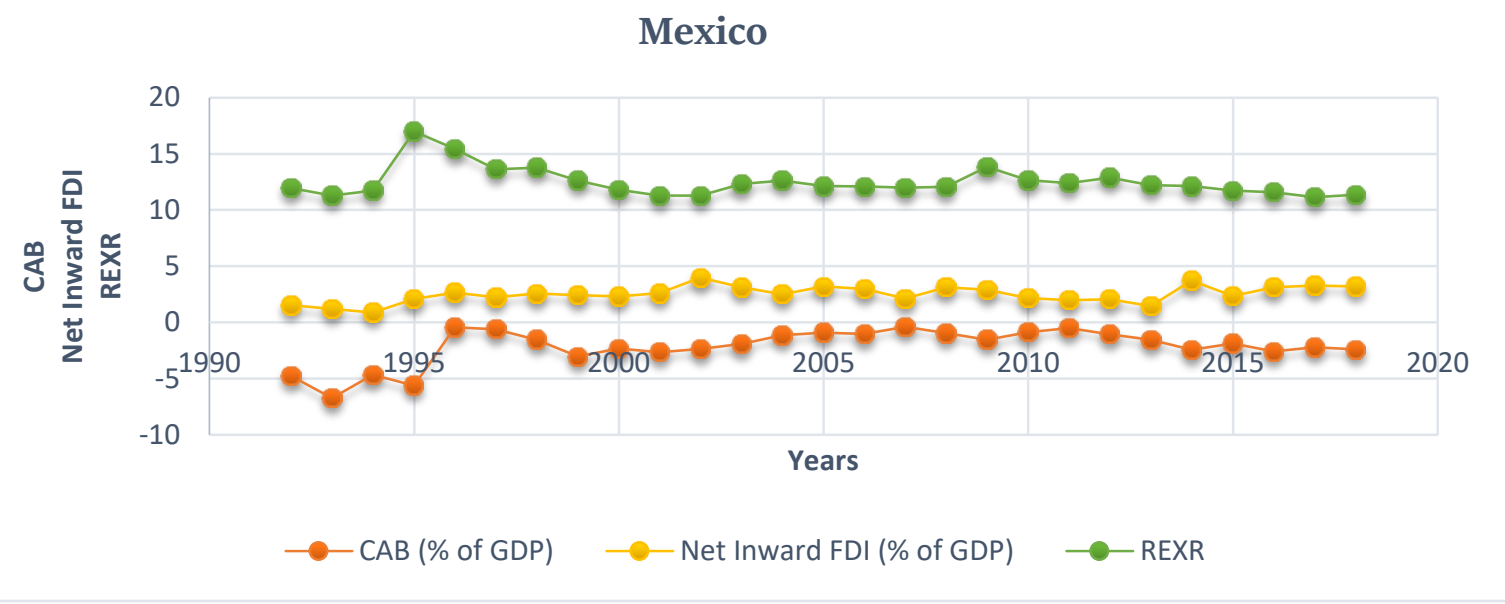

Figure 6: Current Account Balance of Mexico

During the last four decades, a financial opening is an essential ingredient of government policies. The financial flows to this region mainly originated in developed countries of the North and mostly it took the form of foreign direct investment and bank loans. In context to exchange rate arrangements, Latin American countries have experimented with various exchange rate regimes starting from hard peg to floating exchange rate as they employed currency board, intermediate exchange rate options (i.e. crawling peg, moving band), and free-floating exchange rate regime. A brief review of exchange rate arrangements of Latin American countries is reported in section III during the reference period.

The dynamics of the real exchange rate (REXR) and two financial integration measures i.e. net inward FDI and current account balance (CAB) of selected Latin American countries during 19922018 are graphically provided in figure 1 to figure 8 . The graphical inspection of data during the reference period has confirmed strong co-movements between variables. If we closely monitor the trend of the real exchange rate, we can safely deduce that this economic variable has fluctuated substantially in each cross-section of research except Peru as it has relatively stable real exchange during the reference period. In the case of Colombia, the real exchange rate is very high as evident from figure 3 in comparison to other countries. The real exchange rate of Costa Rica is also very high 
after Colombia. A higher real exchange rate in turn is a reflection of higher relative prices at home than abroad.

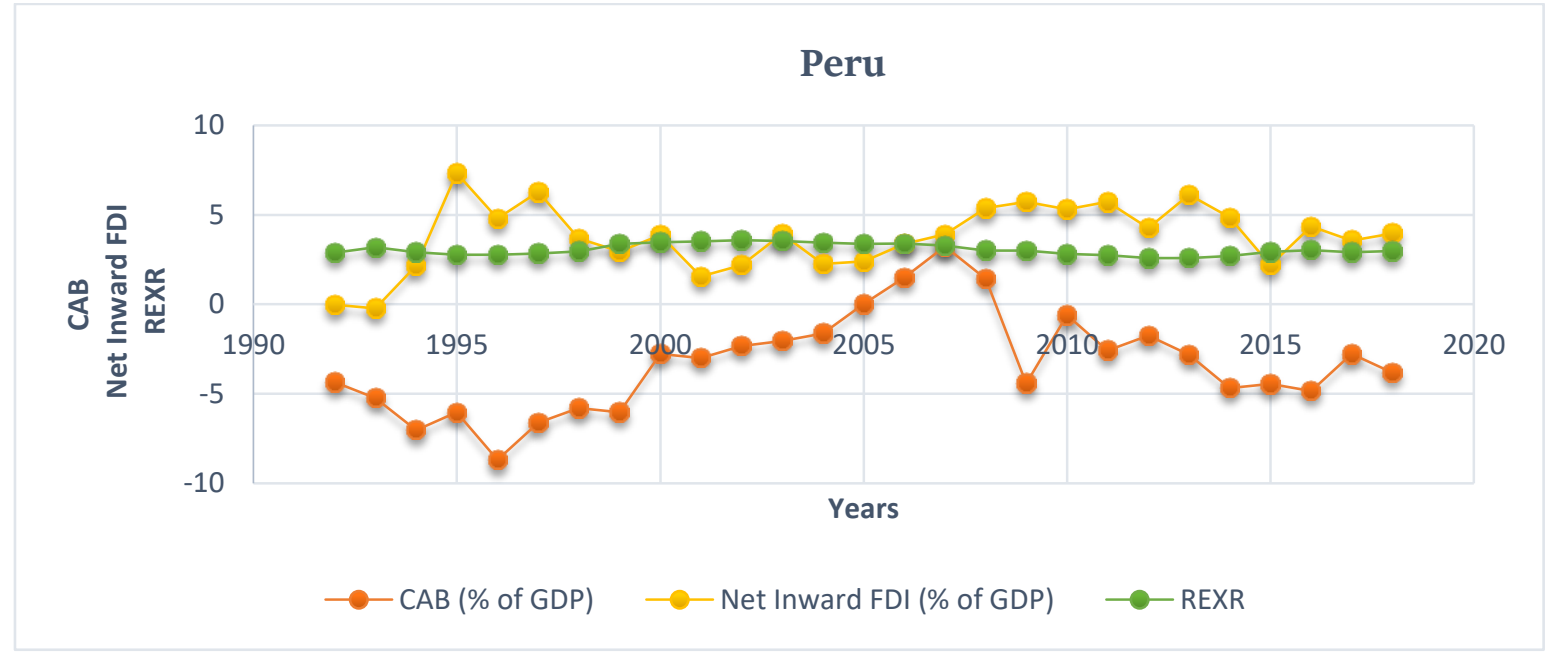

Figure 7: Current Account Balance of Peru

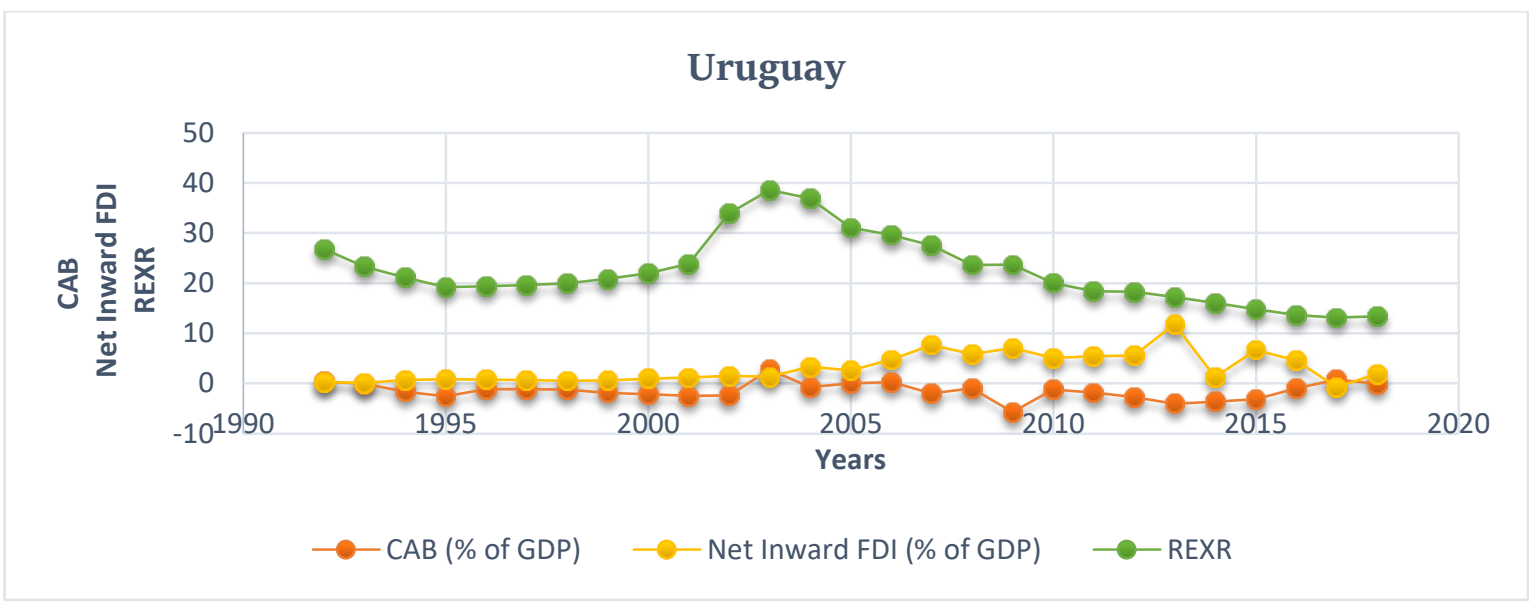

Figure 8: Current Account Balance of Uruguay

This research is aimed at modeling the dynamic linkages between real exchange rate volatility and international financial integration, to explore the impact of real shock and monetary shock on real exchange rate fluctuations, and to utilize the GMM method to address potential endogeneity and country-specific effects of a dynamic model. This research study is structured as following the introduction, section 2 review literature, section 3 provides a brief history of Latin American countries' exchange rate regimes, section 4 discusses data and model, section 5 reports empirical results and discussions, lastly, section 6 concludes the paper with policy implication.

\section{Literature Review}

The critical issue of real exchange rate volatility and its association with international financial integration has deep historical roots in finance literature. Theoretical literature is replete with several studies that have attempted to gauge the association between financial integration and real exchange rate volatility since the 1970s and studies came up with two varyings but the concrete conclusion. According to the first school of thought, there is a positive association between real exchange rate volatility and net foreign assets (a measure of financial integration), for details see, Hooper and Marton (1982), Edwards (1989), Faruqee (1995) and Gagnon (1993). Whereas others 
strongly supported the negative association between exchange rate volatility and financial integration (for details see, Alberto (2003), Darvas (2001), Rahn (2003)). However, limited empirical research is observed on a subject matter with varying results. A brief review of the theoretical and empirical literature is discussed below.

In context to theoretical literature, Dornbusch and Fisher (1980), Gavin (1992) have examined the relationship between real exchange rate and net foreign assets and claimed that any NFA (net foreign assets) shock has the potential to affect the long-run real exchange rate. In aligning with this outcome another comprehensive study undertook by Breton (2004), Egert et al. (2004) concluded that higher NFA stock results in appreciation of real exchange rate due to higher inflows of capital. Le Fort (2000) stated that higher volatility of the real exchange rate can be minimized if there is a higher degree of capital mobility because it has the potential to absorb external shock up to a certain extent. Prasad et al. (2003) also supported that increased financial integration or reduced capital controls has not only mitigated real exchange rate fluctuations but also contributed to raising economic growth in various countries. Another study done by Goldstein and Turner, (2004) pointed out that various positive outcomes can be achieved through financial openness which in turn helps to minimize exchange rate volatility. Those positive outcomes include risk diversification, increase in the liquidity of financial institutions, the effectiveness of consumption smoothing, stimulation of domestic investment, and inflow of foreign investment. Jongwanich (2006) also supported that liberalization of the capital account is useful to mitigate exchange rate fluctuations.

In context to the empirical literature, most research is done to investigate the impact of real exchange rate volatility on various other macroeconomic variables e.g. exports, economic growth, trade, etc. whereas lesser research is diverted to explore determinants of real exchange rate volatility particularly to investigate the impact of foreign capital flows on real exchange rate dynamics. Concerning short term and long term impact of financial integration (measured as the abolition of capital controls) on exchange rate volatility an impressive work done by Obstfeld (1984) who presented a model and asserted that an initial period of real appreciation is observed accompanied by external deficit whereas in the long-run period of real depreciation is observed. Elbadawi (1994) and Hau (2002) among others have empirically examined the association between real exchange rate volatility and international financial integration. Hau (2002) reported that the real exchange rate was less volatile in more financially open economies in comparison to less financially open economies. He has researched twenty-three OECD countries during 1980-1998 covering 19 years.

Colderon (2004) studied the impact of trade and financial openness on the dynamics of real exchange rate fluctuations in the panel of emerging and industrialized economies from 1974 to 2003. By using GMM as an estimation strategy he concluded that financial liberalization has reduced real exchange rate volatility during the reference period. Lane and Milesi-Ferretti, (2005) also attempted to analyze the interactions between financial integration and real exchange rate in a panel of emerging countries during 1990-96. By analyzing assets and liabilities they firmly concluded that a decrease in net external position has depreciated the real exchange rate.

Caporale et al. (2009) panel study on the subject matter gave an analysis of 39 emerging countries comprising Asian, MENA, and Latin American countries. Their findings based on GMM results suggested that during 1979-2004 emerging countries as a whole remained victim to various real, monetary, and external shocks that explain variability in the exchange rate during the reference period. They found a positive association between real exchange rate volatility and financial integration in context to Asian and Latin American countries due to incompatibility of their exchange rate policies with new financial architecture whereas a negative association between the variables is 
observed in MENA countries.

Al-Abri (2013) investigated the impact of terms of trade shocks and financial integration on real exchange rate volatility. They used the GMM method for estimation of panel data comprising of 53 countries (primary exporting countries) during 1980-2007. They concluded that increased financial integration has dampened real exchange rate fluctuations through minimizing the impact of terms of trade shocks. Calderon and Kubota, (2018) conducted a panel study of 82 countries to investigate determinants of real effective exchange rate volatility during 1974-2013. They found that trade and financial integration may potentially increase or decrease real effective exchange rate volatility depending on the type of trade and financial flows. They further elaborated that nonmanufacturing trade has increased real effective exchange rate volatility, whereas, manufacturing trade has stabilized real effective exchange rate volatility during the reference period. The impact of financial integration on exchange rate volatility depends on the share of foreign equity concerning foreign debt liabilities. They also performed a sensitivity analysis to ensure the precision of the estimated results.

Gaies et al. (2019) conducted a study on 72 developing countries using panel data from 19722011. They used the two-step GMM method to empirically investigate the spillover impact of financial globalization on economic growth and concluded that financial globalization approximated by FDI increased economic growth via reducing exchange rate volatility during the reference period.

Nor et al. (2020) empirically investigated determinants of Somalia's exchange rate volatility using a conditional heteroscedasticity model (EGARCH). They used monthly data from 1995 - 2012 and concluded that domestic shocks and various macroeconomic factors (money supply, domestic prices, and imports) are mainly responsible for fluctuations in the unregulated exchange rate.

After reviewing the literature we can safely conclude that empirical literature remains inconclusive owing to differences in selection of cross-sections, selection of period, and choice of estimation strategy. Furthermore, lesser empirical research is observed in the context of Latin American countries therefore this research is intended to evaluate the relative contribution of international financial integration, in particular beside real and monetary shock in explaining fluctuations in the real exchange rate in a panel of Latin American countries which will be a contribution to the existing literature.

\section{Exchange Rate Regimes of Latin America - A Concise History}

The Latin American history of exchange rate arrangements entails macroeconomic interests as it is rich with various exchange rate regimes. Before the 1960 s this region mainly adopted a hard peg or fixed exchange rate regime. During the 1960 s when domestic inflation and resultant exchange rate fluctuations were observed in Brazil and Colombia, both countries shifted to a crawling exchange rate regime whereas others followed hard to peg. However, Argentina, Chile, and Uruguay followed pre-announced crawling rates to curb inflation in the late 1970s but it led to massive real appreciation therefore abandoned during the debt crises of the 1980s. Furthermore, after the debt crises of 1982-83, on average, most of the Latin American countries switched from fixed exchange rate to intermediate exchange rate regimes as Bolivia (1985) and Peru (1990) adopted managed floats. One of the major pitfalls of debt crises was hyperinflation observed in Latin American countries, therefore, mitigation of inflation became a top priority of monetary policy of this region and region started to explore such exchange rate arrangement that gives anchor on price expectations. Hence the region gradually moved towards more flexible exchange rate regimes during 
the 1990s i.e. crawling bands and managed floats except for Argentina which adopted a currency board in 1991 and shifted to a higher fixed exchange rate regime. However, onward to 2005, she followed a flexible exchange rate regime. Table 1 report a summary of exchange rate regimes during 1996-2018 in selected eight Latin American countries used in this research.

Table 1: Summary of Exchange Rate Regimes 1996 to 2018

\begin{tabular}{|c|c|c|c|c|c|}
\hline EXR Regime & 1996(b) & 2000 & 2005 & 2010 & 2018 \\
\hline Currency Board & Argentina (1991) & Argentina & - & - & \\
\hline Crawling Peg & $\begin{array}{c}\text { Bolivia } \\
\text { Costa Rica(1984) }\end{array}$ & $\begin{array}{c}\text { Bolivia } \\
\text { Costa Rica }\end{array}$ & $\begin{array}{c}\text { Bolivia } \\
\text { Costa Rica }\end{array}$ & Bolivia & \\
\hline Moving Band & $\begin{array}{c}\text { Colombia (1994) } \\
\text { Uruguay (1999) }\end{array}$ & Uruguay & - & Costa Rica & \\
\hline Managed Float & & & & & $\begin{array}{c}\text { Costa Rica } \\
\text { Argentina } \\
\text { Bolivia } \\
\end{array}$ \\
\hline $\begin{array}{l}\text { Flexible (with } \\
\text { interventions } \\
\text { in FX market) }\end{array}$ & $\begin{array}{c}\text { Haiti } \\
\text { Mexico } \\
\text { Peru (1990) }\end{array}$ & $\begin{array}{l}\text { Colombia } \\
\text { Haiti } \\
\text { Mexico } \\
\text { Peru }\end{array}$ & $\begin{array}{c}\text { Argentina } \\
\text { Brazil } \\
\text { Colombia } \\
\text { Mexico } \\
\text { Haiti } \\
\text { Peru } \\
\text { Uruguay }\end{array}$ & $\begin{array}{c}\text { Argentina } \\
\text { Brazil } \\
\text { Colombia } \\
\text { Haiti } \\
\text { Mexico } \\
\text { Peru }\end{array}$ & \\
\hline $\begin{array}{l}\text { FIT (Floating } \\
\text { cum Inflation } \\
\text { Targeting) }\end{array}$ & & & & & $\begin{array}{c}\text { Brazil } \\
\text { Chile } \\
\text { Colombia } \\
\text { Mexico } \\
\text { Peru }\end{array}$ \\
\hline
\end{tabular}

Note: (b) refers to information in brackets as year when reported regime in 1996 was introduced, Source: ECLAC (Economic Commission for Latin America and Caribbean) on basis of exchange rate classifications by IMF and official information.

\section{Data and Model}

To empirically investigate dynamic linkages between real exchange rate volatility and international financial integration in selected eight Latin American countries during 1992-2018, we have used balanced panel data and statistics are taken from World Bank, Global Development Finance indicators, various issues, and IMF's International Financial Statistics database.

\subsection{Econometric Model}

Using annual observations following dynamic econometric specification examines the impact of international financial integration on real exchange rate volatility.

$$
\text { EXRvol }_{i t}=\beta_{0}+\beta_{1} \text { EXRvol }_{i t, t-1}+\beta_{2} I F I_{i t}+\beta_{3} C_{i t}+\varepsilon_{i t}
$$

Where, "i" = Country effect, "t" = Time effect, $E X R v o l_{i t, t-1}=$ Lagged real exchange rate volatility, $\beta_{0}=$ Common intercept, $I F I_{i t}=$ Matrix of financial integration indicators (i.e. IFIDJ, IFIDF1 
and IFIDF2), $C_{i t}=$ Matrix of control variables (i.e. Yvol and MBvol) and $\varepsilon_{i t}=$ Stochastic error term. The detailed description of variables is reported in table 2.

Table 2: Description of the Variables

\begin{tabular}{|c|c|l|}
\hline Variable & Symbol & \multicolumn{1}{c|}{ Description } \\
\hline $\begin{array}{c}\text { Real Exchange } \\
\text { Rate Volatility2 }\end{array}$ & REXRvol & $\begin{array}{l}\text { It is calculated using three year moving standard deviation of first } \\
\text { difference of logarithmic of real exchange rate changes. }\end{array}$ \\
\hline \multicolumn{2}{|c|}{ Financial Integration Indicators } \\
\hline Chinn-Ito index & IFIDJ & $\begin{array}{l}\text { International financial integration De-jure measure captured by } \\
\text { Chinn-Ito index. }\end{array}$ \\
\hline $\begin{array}{c}\text { Net Inward FDI } \\
\text { to GDP ratio }\end{array}$ & IFIDF1 & $\begin{array}{l}\text { International financial integration De-facto first measure i.e. net } \\
\text { inward foreign direct investment as percent of GDP. }\end{array}$ \\
\hline CAB/GDP & IFIDF2 & $\begin{array}{l}\text { International financial integration De-facto second measure i.e. } \\
\text { absolute value of current account balance as percent of GDP. }\end{array}$ \\
\hline \multicolumn{2}{|c|}{ Control Variables } \\
\hline Monetary shock & MBvol & $\begin{array}{l}\text { Monetary base volatility measured by three year moving standard } \\
\text { deviation changes in monetary growth. }\end{array}$ \\
\hline Real shock & Yvol & $\begin{array}{l}\text { Output volatility measured by three year moving standard } \\
\text { deviation changes in output growth. }\end{array}$ \\
\hline
\end{tabular}

About the impact of financial integration on exchange rate volatility, literature remains ambiguous as according to Kose et al. (2006), Hau (2002), Deverux and Lane (2003) financial integration is associated with lower real exchange rate fluctuations due to increased risk-sharing whereas Dornbusch (1976) asserted that any nominal shock in perfect capital mobility foreign exchange markets (or freely operating markets) can overshoot exchange rate thus causing an increase in volatility. Concerning the impact of output shock on exchange rate volatility, most of the literature has supported positive association as Friedman (1953) claimed that macroeconomic instability particularly output instability increases exchange rate instability. About the impact of money supply shock on exchange rate volatility, it is expected that shock in money supply can potentially increase exchange rate volatility either through nominal devaluations or through the increase in prices. Supporters of this positive association include Carrera and Vuletin (2002), Calderon (2004), and Morana (2009) among others.

\subsection{Estimation Strategy}

Keeping in view the dynamic panel nature of our proposed model and its associated two major problems i.e. autocorrelation problem due to presence of lagged real exchange rate volatility $\left(\right.$ REXRvol $\left._{i-1}\right)$ variable in the model, secondly, due to fixed effects (time-invariant country

2 It is calculated using moving standard deviation of first difference of logarithmic of real exchange rate (for details see, Thursby and Thursby, (1987)). The mathematical notation of this approach is as follows.

$$
\text { EXRvol }_{i j t}=\sqrt{\frac{\sum_{k=1}^{n}\left(R_{i j,(t-k)}-\mu_{i j t}\right)^{2}}{n-1}}
$$

Where, $\mathrm{n}=$ number of years, $\mathrm{R}_{\mathrm{ijt}}=\mathrm{Ln} \mathrm{REXR}_{\mathrm{ijt}}-\mathrm{Ln}_{\mathrm{REXR}} \mathrm{ijt-1}_{\mathrm{j}}$ (first difference of logarithmic real exchange rate), REXR $\mathrm{i}_{\mathrm{ijt}}=$ Real exchange rate between country " $\mathrm{i}$ " and "j" at time " $\mathrm{t}$ ", $\mu_{\mathrm{ijt}}=$ mean of $\mathrm{R}_{\mathrm{ijt}}$ over " $\mathrm{n}$ " years 
characteristics), we have used GMM method introduced by Arellano and Bond (1991). In the GMM approach instruments play a key role inconsistent estimates. The instruments can be external or internal. Furthermore, the validity of instruments can be confirmed by specification test i.e. secondorder serial correlation test. Another specification test is the Sargan test3 of over-identifying restrictions. According to Arellano and Bond (1991), Kpodar, K. (2007) GMM estimator is a powerful and recommended method to address problems of omitted variables, simultaneity bias, and causality inverse. We have used the first difference GMM approach to control unobserved country-specific effects and to address the endogeneity problem. The lagged dependent and explanatory variables are used as instruments in this research.

\section{Empirical Results and Discussions}

The results of our baseline econometric model on the subject matter are reported in table 3. In the above baseline regression financial integration is captured through policy variable which indicates that it has reduced real exchange rate volatility during 1992-2018. This finding is statistically significant at $5 \%$. The rationale behind this negative association is that during the reference period 1992-2018 selected Latin American countries have significantly abolished capital control restrictions to promote financial integration or cross border capital movements accompanied with implementation of stabilization plans in the early 1990s which in turn succeeded in reducing real exchange rate fluctuations. This empirical finding is consistent with Hau (2002) who asserted that more financial openness leads to lesser real exchange rate fluctuations; however, it contradicts with Caporale et al. (2009) who concluded the positive impact of financial integration in increased volatility of Latin American countries exchange rate during 1979-2004. This contradiction can be due to various reasons as Caporale et al. (2009) study period was 1979-2004 whereas our study time period is 1992-2018 (a period of more financially open Latin American countries). Furthermore, we have excluded those Latin American countries from our sample whose exchange regimes are fixed throughout the reference period whereas Caporale et al. (2009) study included fixed exchange rate regime countries beside other countries.

Table 3: Dynamic GMM Panel Results 1992 to 2018 - Specification I

\begin{tabular}{|c|c|c|c|c|}
\hline Variable & Coefficient & S.E & t-Stat & Prob. \\
\hline REXRvol(-1) & 0.478 & 0.060 & 7.91 & 0.00 \\
\hline IFIDJ & -0.008 & 0.004 & -1.93 & 0.05 \\
\hline Yvol & 0.006 & 0.002 & 2.37 & 0.01 \\
\hline MBvol & 0.002 & 0.0003 & 6.053 & 0.00 \\
\hline Constant & 0.002 & 0.010 & 0.28 & 0.77 \\
\hline \multicolumn{5}{|c|}{ Summary Statistics } \\
\hline \multicolumn{5}{|c|}{$\mathrm{R}^{2}=0.622, \quad$ Adj- $\mathrm{R}^{2}=0.610, \quad$ S.E of regression $=0.058$} \\
\hline \multicolumn{5}{|c|}{ Number of Countries $=8, \quad$ Number of Observations $=216$} \\
\hline \multicolumn{5}{|c|}{$\begin{array}{c}\text { Specification Test - Sargan Test } \\
\text { Ho: Instruments are uncorrelated with error term } \\
\text { Prob. (J-statistic) }=0.22\end{array}$} \\
\hline
\end{tabular}

With regard to the effect of output shock on real exchange rate volatility, our results indicate that $1 \%$ shock in output caused more real exchange rate fluctuations by 0.006 percent whereas $1 \%$

3 This test is intended to check validity of instrumental variables. 
shock in the monetary base has also significantly increased real exchange rate volatility by 0.002 percent. Both results are highly significant and indicate that real shock is more important than monetary shock in explaining real exchange rate fluctuations in Latin American countries. We also observe a positive association between lagged real exchange rate volatility and dependent variable as expected. The summary statistics results are also satisfactory. Given the requirement of GMM, we have used the Sargan test of over-identifying restrictions. Since the reported p-value of J-stat is 0.22 in estimation output therefore we are unable to reject the null hypothesis and safely conclude that instruments are valid and numerical estimates of the regression are consistent. To check the robustness of the results, Tables 4 and 5 report empirics of specification II and specification III on the subject matter.

Table 4: Dynamic GMM Panel Results from 1992 to 2018 - Specification II

\begin{tabular}{|c|c|c|c|c|}
\hline Variable & Coefficient & S.E & t-stat & p-value \\
\hline REXRvol(-1) & 0.492 & 0.060 & 8.13 & 0.00 \\
\hline IFIDF1 & -0.002 & 0.002 & -0.97 & 0.33 \\
\hline Yvol & 0.005 & 0.002 & 2.22 & 0.02 \\
\hline MBvol & 0.002 & 0.0003 & 5.86 & 0.00 \\
\hline Constant & 0.0006 & 0.012 & 0.05 & 0.95 \\
\hline \multicolumn{5}{|c|}{ Summary Statistics } \\
\hline \multicolumn{5}{|c|}{$\mathrm{R}^{2}=0.614, \quad$ Adj- $\mathrm{R}^{2}=0.601, \quad \mathrm{~S} . \mathrm{E}$ of regression $=0.059$} \\
\hline \multicolumn{5}{|c|}{ Number of Countries $=8, \quad$ Number of Observations $=216$} \\
\hline \multicolumn{5}{|c|}{$\begin{array}{c}\text { Specification Test - Sargan Test } \\
\text { Ho: Instruments are uncorrelated with error term } \\
\text { Prob. (J-statistic) }=0.24\end{array}$} \\
\hline
\end{tabular}

Table 5: Dynamic GMM Panel Results from 1992 to 2018 - Specification III

\begin{tabular}{|c|c|c|c|c|}
\hline Variable & Coefficient & S.E & t-stat & p-value \\
\hline REXRvol(-1) & 0.495 & 0.061 & 8.06 & 0.00 \\
\hline IFIDF2 & -0.0004 & 0.002 & -0.18 & 0.85 \\
\hline Yvol & 0.006 & 0.002 & 2.27 & 0.02 \\
\hline MBvol & 0.002 & 0.0004 & 5.81 & 0.00 \\
\hline Constant & -0.006 & 0.011 & -0.55 \\
\hline \multicolumn{3}{|c|}{ Summary Statistics } \\
\hline \multicolumn{4}{|c|}{$\mathrm{R}^{2}=0.611, \quad$ Adj-R ${ }^{2}=0.598$, S.E of regression $=0.059}$, \\
\hline Number of Countries = 8, Number of Observations $=216$ \\
\hline \multicolumn{3}{|r|}{ Specification Test - Sargan Test } \\
Ho: Instruments are uncorrelated with error term \\
Prob. (J-statistic) = 0.25
\end{tabular}

Tables 4 and 5 report results of two specifications of baseline regression with the inclusion of two different financial integration measures i.e. net inward FDI as a percent of GDP and current account balance as a percent of GDP respectively. These results indicate that again there is a negative impact of financial integration on real exchange rate volatility whereas a positive association is reported in context to real and monetary shocks with real exchange rate volatility. However, the 
absence of a significant impact of financial integration on real exchange rate volatility is observed. The positive impact of lagged real exchange rate volatility on current exchange rate volatility is highly statistically significant in all three specifications.

In a nutshell, we can decisively conclude that increased financial integration has played an important role in minimizing real exchange rate fluctuations in Latin American countries during 1992-2018 whereas the impact of nominal shock i.e. shock in money supply on real exchange rate volatility is consistent with imbalance approach to the volatility of real exchange rate (for details see, Fleming (1962), Dornbusch (1976)). Furthermore, the volatility of the real exchange rate in Latin American countries is also attributed to real shock i.e. shock in output. Our empirical results are consistent as suggested by the Sargan specification test in all three specifications and the robustness of the results is also confirmed concerning sign.

\section{Conclusion and Policy Implication}

This study empirically explores the dynamic association of real exchange rate volatility with international financial integration, output volatility, and money supply volatility in selected eight Latin American countries during 1992-2018. It improves deficiency in model specification by utilizing dynamic models and also contributes to the literature by providing empirics on the subject matter in Latin American countries.

The GMM regression results strongly support the positive impact of nominal and real shocks on real exchange rate volatility during the reference period. Secondly, more capital account liberalization is associated with minimizing real exchange rate fluctuations as it has increased liquidity and risk-sharing. The empirical results are consistent with prior expectations. Furthermore, the Sargan test of over-identifying restrictions supported the validity of the econometric model and the consistency of the estimated parameters.

An important policy implication can be drawn from the empirical results i.e. to achieve higher stable exchange rates and to reap its associated benefits Latin American countries needs to pursue those financial, trade, monetary and fiscal policies that aimed to minimize output shocks, money supply shocks, hurdles in financial flows or cross border movement of capital and goods.

\section{References}

Agenor, P.R. (2003). Benefits and Costs of International Financial Integration: Theory and Facts. World Economy, 26(8), 1089-1118.

Al-Abri, A. (2013). Real Exchange Rate Volatility, Terms of Trade, and Financial Integration in Primary Commodity Exporting Countries. Economic Letters, 120(1), 126-129.

Alberola, E. (2003). Real Convergence, External Disequilibria and Equilibrium Exchange Rates In EU Acceding Countries. Banco De Espana, Mimeo.

Arelleno M. \& Bond, S. (1991). Some Tests of Specifications for Panel Data: Monte Carlo Evidence and an Application to Employment Equations. Review of Economic Studies, 58, 277-297.

Baldwin R. \& Martin, P (1999). Two Waves of Globalization, Superficial Similarities and Fundamental Differences. NBER Working Paper 6904.

Bleaney, M. (2008). Openness and Real Exchange Rate Volatility: In Search of Explanation. Open Economic Review 19, pp. 135-46.

Calderon, C. \& Kubora, M. (2018). Does Higher Openness Cause Real exchange Rate Volatility?. Journal of International Economics, 110, 176-204

Calderon, C. (2003). What Derives Volatility in Real Exchange Rates? Evidence from Industrial 
Countries. Central Bank of Chile. Mimeo.

Calderon, C. (2004). Real Exchange Rates in Long and Short Run: A Panel Co-integration Approach. ILADES Georgetown, Review of Economic Analysis, 19(2), 40-83.

Calderson, C. (2004). Trade Openness and Real Exchange Rate Volatility: Panel Data Evidence. Central Bank of Chile, Working Paper 294.

Caporal M. G., Amor H T. \& Rault C. (2009). Sources of Real Exchange Rate Volatility and International Financial Integration: A Dynamic Panel Data Approach. Economics and Finance Working Papers, Brunel University West London.

Carrera, J. \& Guillermo V. (2002). The Effects of Exchange Rate Regimes on Real exchange Rate Volatility: A Dynamic Panel Data Approach. Discussion Papers.

Chinn, M. \& Ito, Hiro. (2006). What Matters for Financial development? Capital Controls, Institutions and Interactions.. Journal of Development Economics, 81 (1),163-192.

Chinn, M. \& Ito, Hiro. (2008). A New Measure of Financial Openness. Journal of Comparative Policy Analysis, Vol. 10, Issue 3, pp. 309-322.

Dell' Ariccia, G. (1999). Exchange Rate Fluctuations and Trade Flows: Evidence from European Union. IMF Staff Papers 46(3).

Devereux, Michael B. \& Philip, R, Lane (2003). Understanding Bilateral Exchange Rate Volatility. Journal of International Economics, 60:109-32.

Dornbusch, R. \& Stanley F. (1980). Exchange Rate and the Current Account. American Economic Review 70, 960-71.

Duarte, Antonia P., Joao S. A. and Adelaide D. (2008). Exchange Rate and International Rate Volatility in Target Zone: The Portuguese Case. Working Paper No. 3

Edwards, S. (1998). Real Exchange Rate in Developing Countries: Concepts and Measurements. NBER Working Paper No 2950.

Egert, B. Lahreche - Revil, A. and Lommatzsch, K. (2004). The stock Flow Approach to the Real Exchange Rate of CEE Transition Economies. CEPII, Working Paper No 15, 4-28.

Faruqee, H. (1995). Long Run Determinants of the Real Exchange Rate: A Stock Flow Perspective. IMF Staff Papers, 42(1), 80-107.

Fischer, S. (1998). Capital Account Liberalization and Role of IMF" in "Should the IMF Pursue Capital Account Convertibility?. Essays in International Finance, Department of Economics, Princeton University, 207, 1-10.

Frankel, J.A \& Rose A.K (1996). Currency Crashes in Emerging Markets: An Empirical Treatment. Journal of International Economics, vol. 41, pp. 351-366.

Frankel, J.A (1999). No Simple Currency Regime is Right for all Countries at All Times. NBER Working Paper 7338.

Friedman, M. (1953. The Case of Flexible Exchange Rates. Essays in Positive Economics, University of Chicago Press.

Gagnon, J. (1993). Exchange Rate Variability and Level of International Trade. Journal of International Economics, No. 34, 269-287.

Gavin, M. (1992). Monetary Policy, Exchange Rates and Investment in Keynesian Economy. Journal of International Monetary and Finance, 11, 145-161.

Goldstein, M. \& Turneip (2004). Controlling Currency Mismatches in Emerging Markets. International Economic Review.

Hau, H. (2002). Real Exchange Rate Volatility and Economic Openness: Theory and Evidence. Journal of Money, Credit and Banking, 4, 611-30.

Hooper, P. \& J. Marton. (1982). Fluctuations in Dollar: A Model of Nominal and Real Exchange Rate Determination. Journal of International Money and Finance,1, 39-56. 
Jongwanich, J. (2006). Exchange Rate Regimes, Capital Account Opening and Real Exchange Rates Evidence from Thailand. Economics RSPAS, ANU.

Kpodar, K (2007). Manuel d' initiation a Stata. CERDI, CNRS, Janvier, 5-77.

Lane, P. R \& Milesi - Ferretti G. M (2005). Financial Globalization and Exchange Rates. IMF Working Paper 03, 4-25.

Le Fort, G. (2000). The Chilean Experience in Capital Account Regulations. Conference on Developing Countries and the Global Financial Architecture, Lancaster House, London.

Morana, Claudie (2009). On the Macroeconomic Causes of Exchange Rate Volatility. International Journal of Forecasting, 25, 328-50.

Morrison, A.D \& white, L. (2004). Financial Globalization and Capital Regulations in Open Economies. Oxford Financial Research Centre Working Paper No. 2004-FE-10.

Mussa M. \& Goldstein M. (1993). The Integrated World Capital Markets. Proceedings Federal Reserve Bank of Konsas City, pp. 245-330.

Nor, I. M. Masron, A. \& Yousif Alabdullah, T. (2020). Macroeconomic Fundamentals and Exchange Rate Volatility: Empirical Evidence from Somalia. SAGE Open, 1-12.

Obstfeld, M. \& Rogoff K.S (1995). Exchange Rate Dynamics Redox.. Journal of Political Economy, 103 (3), 624-66o.

Obstfeld, M. (1998). The Global Capital Market: Benefactor or Menace?. Journal of Economic Perspectives, 12 (4), 9-30.

Quinn, D. (1997). The Correlation of Changes in International Finance Regulations. American Political Science Review.

Quinn, D. (2003). Capital Account Liberalization and Financial Globalization 1890-1999: A Synoptic view. International Journal of Finance and Economics, 8 (3)

Rahn, J. (2003). Bilateral Equilibrium Exchange Rates of the EU Accession Countries against the Euro. BOFIT Discussion Paper No. 11

Reinhart, Carmen M. \& Todd Smith R, (2001). Temporary Controls on Capital Inflows. NBER Working Papers 8422.

Stancik, J. (2006). Determinants of Exchange Rate Volatility: The Case of New EU Members. Centre for Economic Research and Graduate Education - Economic Institute, Discussion Paper 158.

Stiglitz, J. E (2002). Globalization and Its Discontents. New York: Norton.

Thursby, J.G \& M.C Thursby (1987). Bilateral Trade Flows, the Linder Hypothesis and Exchange Rate Risk. Review of Economics and Statistics, 69, 488-95.

Vo, V. (2005). Determinants of International Financial Integration. University of New South Wales NSW 2052 Australia. 